\title{
Role of Humankind in Antibiotic, Antimicrobial- Drug Resistance of Microorganisms
}

\author{
Rajesh Kondabala and Vijay Kumar* \\ Thapar Institute of Engineering and Technology, India
}

Submission: March 02, 2017; Published: April 30, 2018

*Corresponding author: Vijay Kumar, Thapar Institute of Engineering and Technology, Punjab-147004, India, Email: vijaykumarchahar@gmail.com.

\section{Opinion}

Overuse of antibiotics, antimicrobial-drugs by human and animals, leading to complete loss of important and helpful microbes and enhancing the grown and increasing the harmful microbe population. Every living thing tries to survive in every environment, even in stressful conditions by adopting the surrounding conditions and sustain the harsh environment. Without knowing we are providing the microorganisms the conditions which increase the capability to wash out the complete human population. Microorganisms are the vast populated living organisms, many are useful for protecting the immune system from infections and some are harmful too. By the discovery of penicillin by Sir Alexander Fleming in 1928 [1,2] started a modern era of antibiotics. Penicillin saved millions of lives during world war-II [1].

Thereafter, major growth took place in the antibiotic discovery that played a key role in modern medicine. Until the first case of methicillin-resistant Staphylococcus aureus (MRSA) is identified in 1962 [1,3]. After this the effectiveness of antibiotics decreases suddenly, resistance has eventually observed for almost all antibiotics that have been developed [3]. Even though vancomycin was introduced for curing MRSA in clinical practices, unfortunately, bacteria developed resistance to this antibiotic to [1]. We are responsible for the antibiotic resistance by overuse of antibiotics and drugs. Bacteria are getting evolved because of antibiotic overuse, which increases the resistivity towards the antibiotics and drugs [4,5]. Where the inheritance takes place in the bacteria that passes to the next generation. Spontaneous mutations can also help in developing resistance. Through natural selection, the bacteria reproduce the resistance offspring because of losing drug sensitivity by antibiotics $[3,6]$. Not only within itself have bacteria also had the ability to transfer resistance to other bacteria through horizontal gene transfer (HGT) [6]. Subinhibitory and subtherapeutic antibiotic concentrations can promote the development of antibiotic resistance by supporting genetic alterations, such as changes in gene expression, HGT, and mutagenesis (Figure 1).

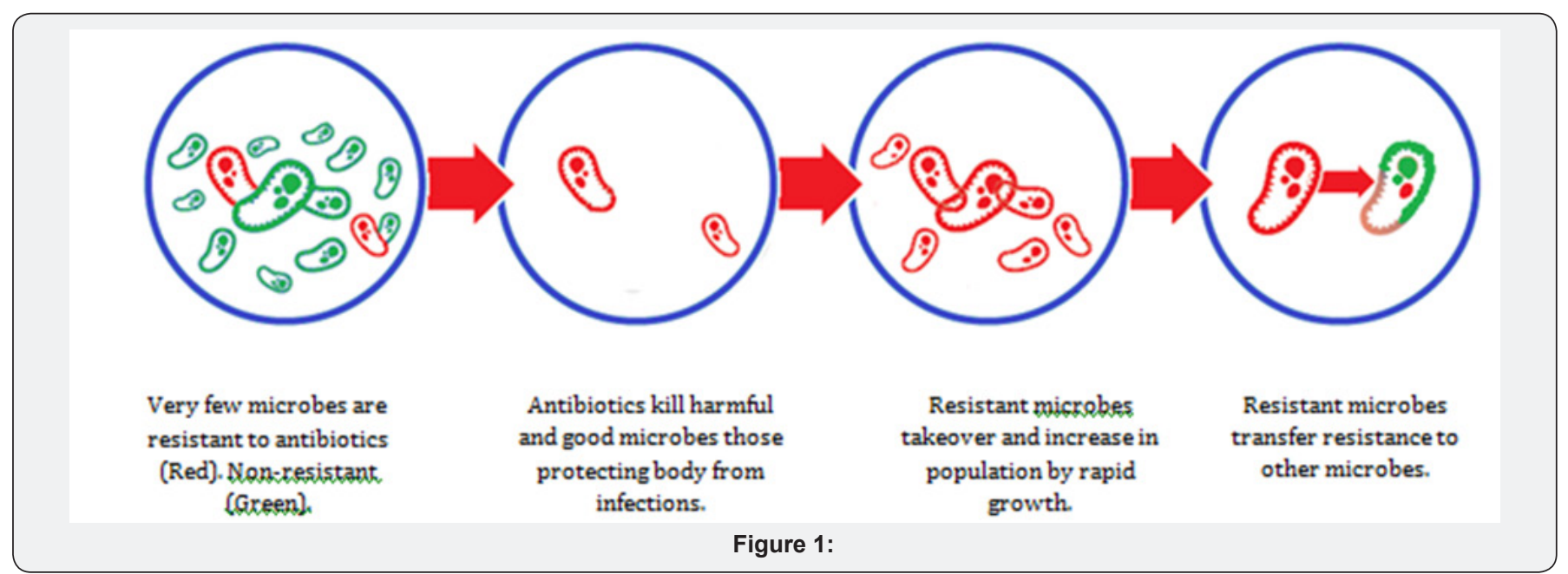

We are neglecting the antibiotic and antimicrobial drugs overuse alarm [6]. Now a day's commercial company advertising many different kinds of antibiotics, drugs, and disinfectants promising they can kill the germs and that increase the immunity.
We are completely losing our resistance and immunity towards harmful germs. Exposing to fewer germs is also very important part of immunizing our own system this is also known as acquired immunity. This type of immunity stimulates the immune system 
readily with the memory cells those can protect our system in a future attack by the same microbes.

We use many chemicals, gels, and bars to kill the microorganisms, but we are forgetting that we are creating a stressful environment for the microorganisms which force them to evolve for the survival. Here comes the problem once the microorganisms start evolving, nothing can stop them. If we think of a new drug to kill them, they again build up resistance power against the new drug (Figure 2). Using more antibiotics, drugs, and chemicals to kill germs may also completely wash out the useful microbes which help in protecting our immune system and helps in the digestion process. Now the antibiotic/drugresistant microbes grow faster and spread throughout the body. And those microbes pass the resistivity to their neighboring microbes [7-11].

\section{"As our ancestors say prevention is better than cure"}

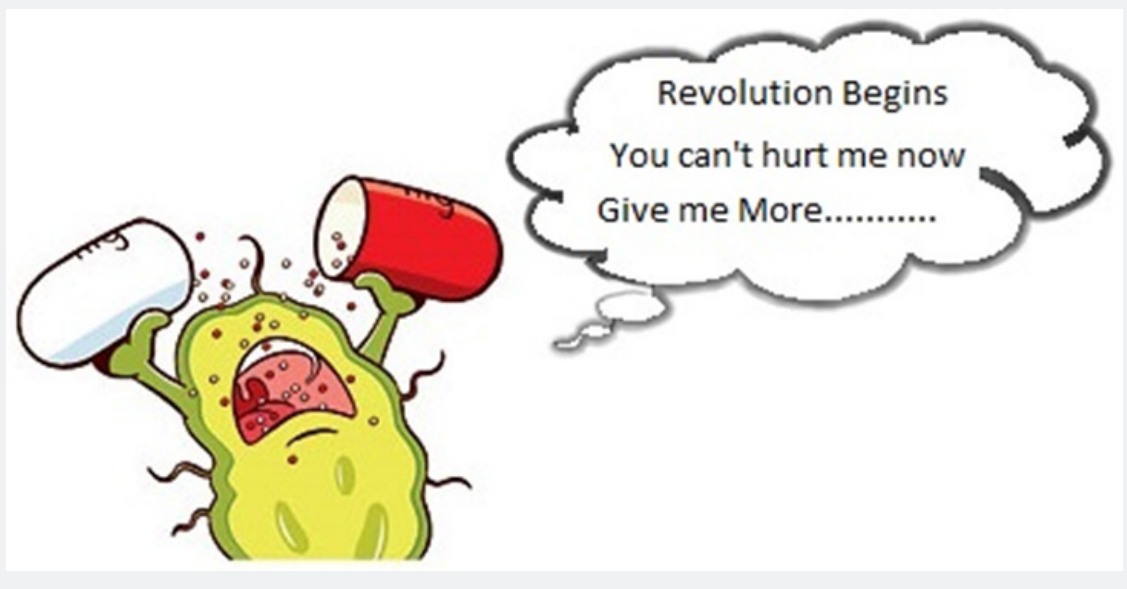

\section{Conclusion}

It is being important to keep out ourselves from harmful and deadly microorganisms, but also protects the helpful and immune protective microbes. Sometimes it is good to have infections which improve our immune system and activates it for a future attack. Without a well-trained physician, prescription doesn't use antibiotics or drugs. Reduce the use of any antigerm and disinfectant gels or chemicals. Eat a healthy and nonprocessed food, exercises every day and stay happy this keep you active and protect you from harmful microbes. This practice keeps us healthy and wealthy from reducing our medical bills.

\section{References}

1. Sengupta S, Chattopadhyay MK, Grossart HP (2013) The multifaceted roles of antibiotics and antibiotic resistance in nature. Front Micro boil $4: 47$.

2. Piddock LJ (2012) The crisis of no new antibiotics-what is the way forward? Lancet Infect Dis 12(3): 249-253.
3. Centers for Disease Control and Prevention, Office of Infectious Disease (2013) Antibiotic resistance threats in the United States.

4. Spell berg B, Gilbert DN (2014) The future of antibiotics and resistance: a tribute to a career of leadership by John Bartlett. Clin Infect Dis 59: S71-S75.

5. Read AF, Woods RJ (2014) Antibiotic resistance management. Evol Med Public Health (1): 147.

6. Bartlett JG, Gilbert DN, Spell berg B (2013) Seven ways to preserve the miracle of antibiotics. Clin Infect Dis 56(10): 1445-1450.

7. The antibiotic alarm (2013) Nature 495(7440): 141.

8. WHO (2012) Antimicrobial resistance in the European Union and the world. World Health Organization, Geneva, Switzerland.

9. CDC Threat Report 2013 Antimicrobial Resistance. USA.

10. WHO Europe Antimicrobial resistance. World Health Organization, Geneva, Switzerland.

11. WHO Antimicrobial resistance. World Health Organization, Geneva, Switzerland. 

(C) Commons Attribution 4.0 License

DOI: $10.19080 / \mathrm{IJCSMB} .2018 .04 .555641$

\section{Your next submission with Juniper Publishers} will reach you the below assets

- Quality Editorial service

- Swift Peer Review

- Reprints availability

- E-prints Service

- Manuscript Podcast for convenient understanding

- Global attainment for your research

- Manuscript accessibility in different formats ( Pdf, E-pub, Full Text, Audio)

- Unceasing customer service

Track the below URL for one-step submission https://juniperpublishers.com/online-submission.php 